\title{
Access and allocation in earth system governance: water and climate change compared
}

\author{
Joyeeta Gupta $\cdot$ Louis Lebel
}

Accepted: 1 April 2010/Published online: 5 October 2010

(C) The Author(s) 2010. This article is published with open access at Springerlink.com

\begin{abstract}
A significant percentage of the global population does not yet have access to safe drinking water, sufficient food or energy to live in dignity. There is a continuous struggle to allocate the earth's resources among users and uses. This article argues that distributional problems have two faces: access to basic resources or ecospace; and, the allocation of environmental resources, risks, burdens, and responsibilities for causing problems. Furthermore, addressing problems of access and allocation often requires access to social processes (science, movements and law). Analysts, however, have tended to take a narrow, disciplinary approach although an integrated conceptual approach may yield better answers. This article proposes a multi-disciplinary perspective to the problem of access and allocation and illustrates its application to water management and climate change.
\end{abstract}

Keywords Climate change - Distributive issues - Human rights - Social justice · Water governance

$\begin{array}{ll}\text { Abbreviations } \\ \text { ILA } & \text { International Law Association } \\ \text { IPCC } & \text { Intergovernmental Panel on Climate Change } \\ \text { OECD } & \text { Organization for Economic Cooperation and Development } \\ \text { UN } & \text { United Nations } \\ \text { UNCED } & \text { United Nations Conference on Environment and Development } \\ \text { UNDP } & \text { United Nations Development Programme }\end{array}$

J. Gupta $(\bowtie)$

Institute for Environmental Studies, VU University Amsterdam, Amsterdam, The Netherlands e-mail: joyeeta.gupta@ivm.vu.nl

J. Gupta

UNESCO-IHE Institute for Water Education, Delft, The Netherlands

L. Lebel

Unit for Social and Environmental Research, Chiang Mai University, Chiang Mai, Thailand 
UNHCR United Nations High Commissioner for Refugees

WECF Women in Europe for a Common Future

WHO World Health Organization

\section{Introduction: the two faces of distributional problems}

Globally, while human society is developing rapidly, distributional problems persist. These distributional problems have two faces. The first face is the lack of access to basic resources: 1-2 billion people do not have access to potable drinking water and sanitation facilities; more than 2 billion do not have access to energy services. The lack of access to basic necessities such as food, water, shelter and energy threatens human security (e.g. UN Energy 2005; Modi et al. 2005). Access is a problem not only significant among countries but also within them.

The second face is how resources are distributed among and between communities and nations over and above the issue of access to minimum resources. Many distributional problems are historical, reflecting social discrimination, conquests, colonization, and processes consolidating land and water ownership in the hands of the few. In recent decades, globalization and global governance processes (e.g. eco-labelling, intellectual property rights, access and benefit sharing in the biodiversity regime) often have had intended or unintended impacts on vulnerable or otherwise disadvantaged communities and nations. These processes have led to the concentration of wealth and power. Since environmental resources and economic wealth are often closely related, control over such resources becomes a paramount motivating factor in political economy.

The problem of access and allocation is thus central to earth system governance (Biermann 2007; Biermann et al. 2009, 2010). This article proposes a multi-disciplinary perspective, develops a conceptual framework, and shows briefly how such a perspective can be applied by examining two cases: climate change and fresh water.

These two cases were chosen since although they are different they pose some similar problems when it comes to the issue of access and allocation. While water governance goes back more than five thousand years, climate change governance has been on the agenda for only two decades. While water governance was primarily seen as a local issue, the common hydrological cycle, the cumulative impacts of water use and misuse, and the comparative problems and patterns of water management in different parts of the world are increasingly demonstrating the global nature of the water problem. Climate change governance was seen from the early 1990s as a global governance issue that needed to be complemented by governance at other administrative levels. Despite these differences, there are similarities. Water and climate governance focus on managing scarce resources; clean water in the first case, and in the case of climate change, the scarce resource is the 'ecospace' . Both include complex distributional issues regarding how these scarce resources should be shared between communities and countries. Both the water and climate change regimes must deal with issues of who gets what, according to contested principles, and subject to social relations and pressures. As such, these two issues offer good cases for this article, allowing for comparison of the way in which access and allocation are dealt with in the two different subject areas.

1 Ecospace or environmental utilization space is a concept used to denote the total amount of resources available for use or the total amount of the sink available for the disposal of wastes. 


\section{Access and allocation}

Access and allocation are closely intertwined. This section elaborates on how different disciplinary approaches lead to different articulations of these two closely related issues. Political science scholars often define these in terms of who gets what, when, where and how. Legal scholars may focus on norms and normative forcing. Economists deal with markets and pricing mechanisms. Sociologists emphasize how justice is locally negotiated and defined and the role of social relations and movements in this (Dryzek 2000; Rorty 1992; Elster 1992, 2006). A geographical perspective would explore the consequences of physical location and identify areas of high vulnerability. Natural scientists may study how to deal with the physical, chemical, and biological limits to access. An earth system governance approach merges these different perspectives to study access and allocation in an interdisciplinary and integrated way at multiple levels. Table 1 below sets out an initial conceptual framework on access and allocation.

This article defines access in terms of the ability of individuals to secure a basic minimum of resources and ecospace. This can be implemented through a market mechanism in societies where all have adequate resources to pay for these services. Where this is not the case, the notion of human rights and/or free, subsidized or rationed access to a certain minimum amount of basic resources for the poorest could be appropriate. Access to basic resources can also be enhanced by technological options, or limited by physical shortage.

The concept of human rights recognizes the basic rights and freedoms of every human being to live in dignity. Human rights have existed for long, are found in different systems of governance, in philosophical works (e.g. Paine, Mill, Hegel) and have been promoted by social movements led by Gandhi, the Red Cross, Amnesty International and indigenous peoples groups - to name a few. Human rights are recognized in national and international legal instruments, but have not always been explicitly articulated in terms of the basic rights for water, food, shelter, and sanitation. In recent years a needs based perspective has been given impetus with the adoption of the Millennium Development Goals in 2000. Likewise a rights based approach has been encouraged since 2008 under the auspices of the UN Human Rights Council.

Allocation goes beyond the issue of meeting basic needs and looks at how the remainder of the resources can best be divided among people and countries. Allocation thus has three dimensions: how (a) resources are shared; (b) risks and burdens are distributed; and, (c) responsibilities for causing environmental problems. The first dimension focuses on how land, water, minerals including oil, forests, species and ecosystems and their services are shared. The second and third looks at how problem situations are dealt with from the perspective of the 'affected' and the 'responsible', respectively.

Early mercantilists who accessed foreign resources through trade found that access and allocation issues eased with ownership or concession contracts and that led to colonization. Post-colonization claims over mines and lands led the newly independent states to nationalize these assets or call for permanent sovereignty over natural resources (Schrijver 1995). Access to and allocation of rights from mines, forests and the resources within them and access to legal systems of justice were then gradually institutionalized through trade rules (which enabled any person/organization from anywhere in the world to have access to such resources if these resources were to be open for private sector participation or were available for purchase) and investment agreements (which enabled foreign investors to be able to go to international arbitration to protect their investments; Tienhaara 2009). 
Table 1 Towards a multi-disciplinary governance framework on access and allocation

\begin{tabular}{|c|c|c|c|}
\hline Discipline & Issues & Access & Allocation \\
\hline \multirow[t]{2}{*}{$\begin{array}{l}\text { Inter- } \\
\text { disciplinary }\end{array}$} & & $\begin{array}{l}\text { Whether the basic needs of } \\
\text { humans should be met and } \\
\text { what these needs are; what } \\
\text { instruments can be used to } \\
\text { ensure that these needs are } \\
\text { met? }\end{array}$ & $\begin{array}{l}\text { How are environmental } \\
\text { resources shared; how are } \\
\text { risks and burdens distributed; } \\
\text { how are responsibilities for } \\
\text { causing environmental } \\
\text { problems allocated? }\end{array}$ \\
\hline & & \multicolumn{2}{|c|}{$\begin{array}{l}\text { What is the role of science, social actors and movements, and } \\
\text { power in promoting discourses? }\end{array}$} \\
\hline $\begin{array}{l}\text { Political } \\
\text { science }\end{array}$ & $\begin{array}{l}\text { Who gets what, when, } \\
\text { where, and why? }\end{array}$ & $\begin{array}{l}\text { How should the poorest be } \\
\text { dealt with? How do they } \\
\text { represent their interests? Who } \\
\text { resists efforts to guarantee } \\
\text { access, and why? }\end{array}$ & $\begin{array}{l}\text { How does allocation of } \\
\text { resources amongst social } \\
\text { actors take place? What } \\
\text { factors influence this? }\end{array}$ \\
\hline Law & $\begin{array}{l}\text { What principles are } \\
\text { relevant and how can } \\
\text { these be implemented? }\end{array}$ & $\begin{array}{l}\text { Is a human rights' (or a human } \\
\text { needs) approach appropriate? }\end{array}$ & $\begin{array}{l}\text { How do equity principles } \\
\text { interact with existing } \\
\text { ownership principles in } \\
\text { determining allocation? }\end{array}$ \\
\hline Economics & $\begin{array}{l}\text { What role does the } \\
\text { market and market } \\
\text { based instruments } \\
\text { play? }\end{array}$ & $\begin{array}{l}\text { Can subsidies and incentives } \\
\text { deal with the issue of access? } \\
\text { How do production- } \\
\text { consumption relationships } \\
\text { affect access? }\end{array}$ & $\begin{array}{l}\text { Is the market able to allocate } \\
\text { resources? Can market-based } \\
\text { instruments help in re- } \\
\text { distribution in so far as that is } \\
\text { needed? }\end{array}$ \\
\hline Sociology & $\begin{array}{l}\text { What role do social } \\
\text { relations and } \\
\text { movements play? }\end{array}$ & $\begin{array}{l}\text { How do social relations } \\
\text { influence rights of access? } \\
\text { How have social movements } \\
\text { affected access? }\end{array}$ & $\begin{array}{l}\text { How do social relations and } \\
\text { movements shape the } \\
\text { institutions that allocate } \\
\text { benefits, risks and burdens? } \\
\text { What are the outcomes in } \\
\text { terms of gender, class and } \\
\text { ethnicity? }\end{array}$ \\
\hline Geography & $\begin{array}{l}\text { Where are the most } \\
\text { vulnerable people } \\
\text { located? }\end{array}$ & $\begin{array}{l}\text { How does physical location } \\
\text { influence access? }\end{array}$ & $\begin{array}{l}\text { How can challenges of scale in } \\
\text { allocation issues be } \\
\text { addressed? }\end{array}$ \\
\hline $\begin{array}{l}\text { Natural } \\
\text { scientists }\end{array}$ & $\begin{array}{l}\text { What physical, } \\
\text { biological, geological } \\
\text { and chemical } \\
\text { characteristics } \\
\text { determine access? }\end{array}$ & $\begin{array}{l}\text { Are there physical limits to } \\
\text { specific resources that } \\
\text { hamper access? }\end{array}$ & $\begin{array}{l}\text { Are there physical } \\
\text { characteristics of a specific } \\
\text { resource or problem that } \\
\text { shapes allocation rules? }\end{array}$ \\
\hline
\end{tabular}

At the international level, principles of resource sharing are dealt with through sovereignty. The principle of absolute territorial sovereignty allowed countries to own everything within their jurisdiction and to do what they liked with it. This principle is now subject to the idea that no harm should be caused to others (principle of limited territorial sovereignty; the 'no harm' principle). At the national level, while initially countries appeared to have sovereignty, this sovereignty has been pierced through trade and investment agreements that grant foreigners many rights to resources (principle of nondiscrimination) within countries (Ferguson and Gupta 2002; Agnew 2005).

Within countries, historical access and ownership rules led to a concentration of power and access to resources in the hands of the few-who also had a key role in institutionalizing rules that protected these rights. In Scotland, for example, land ownership is 
concentrated in the hands of a very small minority even today. In many common law countries, similar patterns of concentration of land and water ownership can be seen. Efforts to redistribute such land and water rights are taking place in different parts of the world in different ways (e.g. South Africa, Zimbabwe).

The challenges of the distribution of burdens and risks, and responsibilities for environmental problems are relatively new; however, past inequities often become exacerbated by new inequities. With industrialization, actions in one area can have impacts elsewhere. With globalization, actions in one country can have impacts in other countries. The burdens and risks of these actions are distributed unequally. At present, there are no clear mechanisms for allocating responsibilities for dealing with these risks. The 'polluter pays' principle adopted within the OECD has a limited geographical applicability and is mostly defined in terms of cost-internalization and not in terms of compensating victims. The noharm and liability principles have been developed in some countries and at the international level, but their application to global environmental problems has been limited. Anand (2004) explores how environmental justice has been dealt with in three regimesclimate change, ozone politics and the transboundary movement of hazardous wastes to argue that no clear pattern of rules exists. She argues, based on considerable literature, that the dominant environmental paradigm today has a number of elements. It institutionalises unequal enforcement, trades human health for profit, places the burden of proof on the victims and not the polluting industries, legitimates human exposure to harmful chemical and hazardous substances, promotes unsafe technology, exploits the vulnerability of disenfranchized communities, subsidises ecological destruction, delays clean up action, and fails to develop pollution prevention as the overarching and dominant strategy. In contrast, the environmental justice paradigm would enhance public participation in decision-making, empower communities, build infrastructures for promoting justice and sustainable communities, promote holistic approaches to health, develop risk reduction strategies, privilege social to economic profits, and seek equitable distribution (Anand 2004, 11).

A third element is access to social processes which includes access to social movements and systems of justice that mobilize both human capital and technical and technological solutions to the problem. Although the notion of human rights and/or subsidized access to basic resources may help to conceptually guarantee access, in practice there are many challenges. Why should societies adopt such rights and/or offer or allow access to basic needs free of cost? How can such access and principles of allocation be implemented?

Access and allocation also depend on the role of social actors, coalitions, and movements in debating, promoting and pushing for these ideas, mobilizing resources, science and technology and actually ensuring implementation of such ideas (Dryzek 2000; Young 2001). This is where the study of actors and how they promote specific discourses at different levels of governance and spatial locations is needed (Lebel et al. 2005; Dore and Lebel 2010a). Domestic and transnational civil society organizations, as well as individuals, can, through their protests, appeals, use of media, advocacy, lobbying and litigation activities as well as through promoting greater technical research impact access conditions. More subtly, sympathetic local government officials may behave in ways that moderate and even counter central government policies out of concerns for livelihoods and allow technically 'illegal access' on humanitarian grounds as part of routine operations, or in continuation of past social practices. Thus, in areas where people live in protected areas or forest reserves without tenure and rights to farm land, local authorities may respect local systems of property rights including access to land, trees and water. Access in practice and on paper can diverge substantially in the real world, and often do so, in developing 
countries and remote locations, thus creating plural systems of law and governance (Ribot and Peluso 2003; Neef et al. 2006).

Rights are not self-enforcing: rights without access to systems of implementation and justice are meaningless. Thus, if human rights are accepted, there needs to be access to systems of justice at national and international level to ensure implementation of those rights. Pro bono litigation can help secure implementation of rights for the poorest, especially where the locus standi issue is resolved. Similarly, allocation issues often are mired in historical systems of rights (e.g. the case of the Nile). Reallocating resources may call for changes in science, discourses, and/or social movements in order to shift from past patterns of ownership in a fair manner. However, some of these challenges can perhaps be addressed by scientific and technical research on enhancing the efficiency or substitution of resource use. Figure 1 tries to incorporate the main ideas in the above text in a conceptual framework.

Resource characteristics

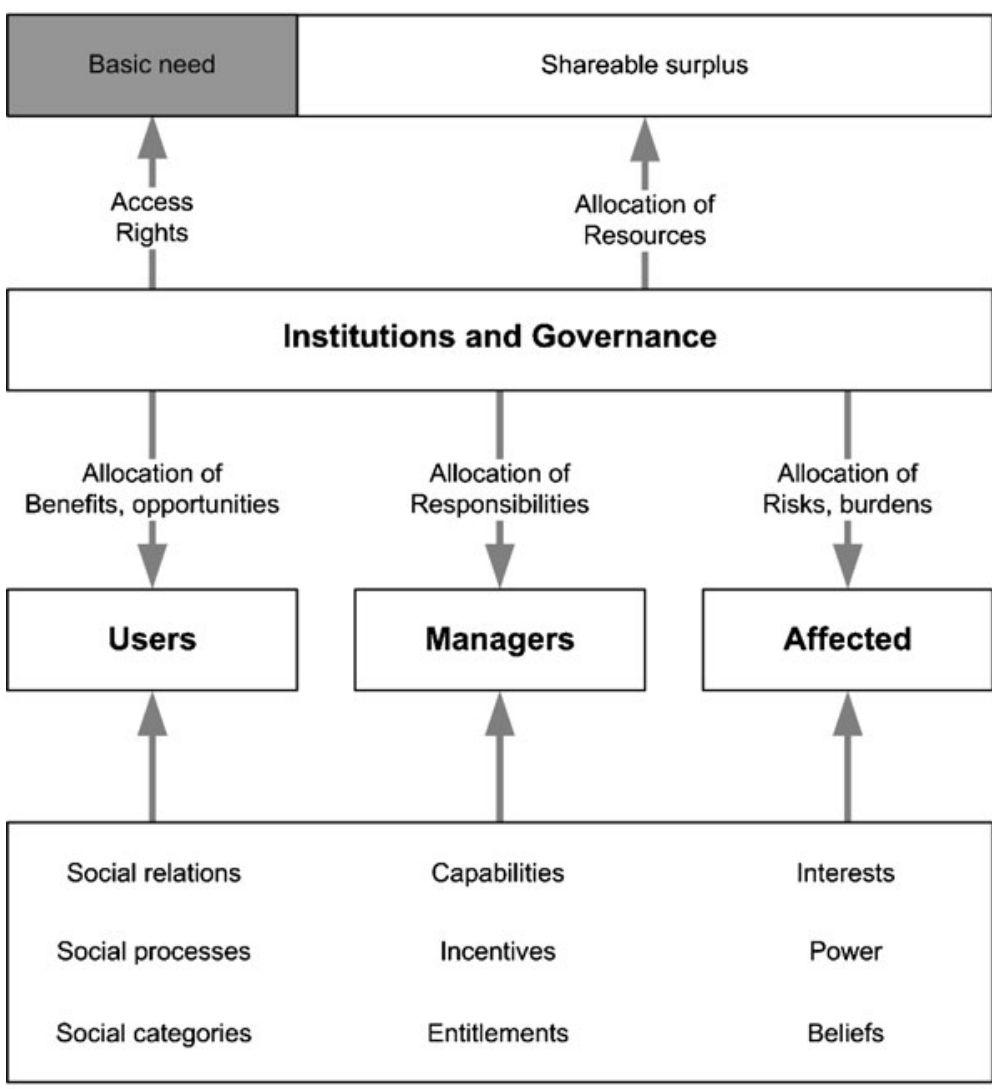

\section{Social context}

Fig. 1 An initial conceptual framework for the role of institutions and governance in shaping individual access to and allocation of resources (and ecospace) in the earth system 


\section{Water governance}

We now turn to our first case study on water governance and study this in terms of access and allocation. Following a brief history of water governance, this section discusses the access and allocation challenges in water governance and the role of social movements and science in water governance. Governance on water goes back thousands of years. Rules on access and allocation can be found in ancient Hindu law (e.g. Donger and Smith 1991 (translation) and politics (Rangarajan 1987 (translation): 73-74), Islamic law (e.g. Naff 2008) and Roman law (e.g. Caponera 1992). In common law, 'stripped to its essentials the riparian rights doctrine means that the only ones who hold the right to use water are those who have access to it through ownership of land' (Teclaff 1985: 6). Access and allocation has been based on community solidarity (Hindu law), right of thirst (Islamic law), basic needs (communism), land ownership (riparianism), prior appropriation, and increasingly through licenses or payment.

There is a constant struggle between those who see water as a resource that should be harnessed for development (the big development banks, irrigation officials and farmers); having multiple functions and ecosystem services; or a living being. Water governance at national level often consists of a complex of rules and regulations. Relatively few developing countries have an integrated water policy (e.g. Brazil, South Africa), while many of the 150 or so developing countries have highly pluralist water law systems (e.g. in Africa). In developed countries such systems often take water rights and water allocation principles into account, although the rights of indigenous peoples may be contested-and the basic sanitation rights of about 20 million European Union citizens especially in the new member countries have not yet been met (WECF 2008). In many developing countries, water access remains a critical challenge as more than 1.2 billion people lack access, and allocation between the different sectors is disputed because of the scarcity of water resources (Molle et al. 2009; Dellapenna and Gupta 2009).

Access to water for drinking and sanitation purposes is critical for human health, productivity and dignity. The burden of lack of access falls mostly on women and children. Basic needs amount to about 15-20 (UNHCR) to 501 (WHO) per person per day depending on the body that makes these calculations. The Millennium Development Goals of 2000 acknowledged the need to politically prioritize this problem, the UN Human Rights Council set in motion a process to further elaborate on these rights in 2008, and in July 2010 the UN General Assembly has adopted a Resolution on the Human Right to Water and Sanitation.

For legal scholars, the access problem is one of water rights (e.g. Bourquain 2008); for economists one of water pricing, subsidies and private sector participation; for engineers one of infrastructural solutions (e.g. dams, interbasin transfers); for sociologists the challenge is to find ways to negotiate institutional solutions (Lebel et al. 2007) for multidisciplinary scholars on how infrastructural solutions and governance are interlocked (Gupta and van der Zaag 2008).

The human right to water has been discussed extensively in the literature (Smets 2000; McCaffrey 1992; Hildering 2005) and adopted in UN circles (General comment 2002). Access to water can also be guaranteed by price variations and subsidies for the poor and this has been undertaken in many countries. At the UN Conference on Environment and Development of 1992 (UNCED 1992: para 18.8), a compromise between the human rights and the economic good idea was adopted. However, in practice in the 1990s and early 2000s, there was considerable pressure for water privatization and as a result the price of water increased (Barlow and Clarke 2002; Petrella 2001) and marginalized groups have 
been further disempowered. This has led to arbitration following breach of contracts (Tecco 2008; Schouten and Schwartz 2006).

Allocation of water is about (a) how water resources are shared between different uses and sectors, (b) how risks are shared, and (c) how responsibilities for causing problems are shared. These are issues that call for more systematic research.

Societies have traditionally laid down rules about how to share water across different uses. At international level, there is a rich history of sharing water and, in specific basins, rules have developed on sharing water ${ }^{2}$ (Salman and Uprety 2002), power, and even scenic beauty $^{3}$ (Benvenisti 2003; Dellapenna and Gupta 2009; Fuentes 1999). Allocation rules reflecting state practice are synthesized in 11 criteria included in the 1966 Helsinki Rules adopted by the International Law Association (ILA 1966); and the 1997 United Nations Convention on the Non-Navigable Uses of International Watercourses (UN Watercourses Convention 1997). ${ }^{4}$ However, these criteria challenge the permanence of property rights and historical rights and are politically contested, and the latter convention never entered into force. These criteria may also be inadequate to deal with the new challenges (e.g. climate change, and the need to reserve water for ecosystem services). The ILA's Berlin Rules tries to deal with some of these newer issues (ILA 2004).

Sometimes, the heated discussions on allocation can be eased by technical solutions such as reservoirs, dams and inter-basin transfers. However, such constructions alter ownership and access patterns, often transforming previous customary owners into victims of submergence, and thus creating new rules of access and allocation, concentrating power in the hands of the few (Conca 2006; Molle et al. 2009). For instance, the World Commission on Dams' recommendations, although heavily cited, were never seen as entirely legitimate (because of the status of the Commission) (Dingwerth 2004) nor were they actively and effectively implemented (Fink and Cramer 2008; Scheumann 2008; Dore and Lebel 2010b).

Within the domestic context, allocation of resources between uses and sectors is highly contested. Although the agricultural sector is the dominant user of water resources globally, decisions regarding how much water is allocated to this sector are highly political. Some argue that water scarce countries should import food from water rich countries (Luterbacher and Wiegandt 2005) while others would see this as challenging both notions of food security and employment for local farmers. As water is seen more and more as an economic good there is a possibility that water will be channelled more for its high-value uses than its low-value uses, but this could lead to a shift from low value rural waters to high value water use such as in industries and golf fields (Tarlock 2005). Allocation is increasingly subject to ownership rules and market mechanisms. Even so, privatization has not always been successful (Dellapenna 2009 for the United States, Schouten and Schwartz 2006; Tecco 2008 for the developing countries). In the developing world, allocation rules are highly contested, not only because of the concentration of water ownership, but

\footnotetext{
${ }^{2}$ For example, the waters of the Indus have been divided between India and Pakistan through allocating three tributaries to India and three to Pakistan.

${ }^{3}$ For example, the 1950 treaty between US and Canada allows the flow of the Niagara to be left undisturbed to ensure that both countries can enjoy its natural beauty.

${ }^{4}$ These criteria include the geography of the basin, the hydrology of the basin, the climate affecting the basin, the past utilization of the waters of the basin, the economic and social needs of the basin states, the population dependent on the waters, the comparative costs of the alternative means of satisfying the economic and social needs of each basin state, the availability of other resources, the avoidance of unnecessary waste, the practicability of one state to compensate the other, the degree to which the needs of a basin state can be satisfied without causing substantial injury to a co-basin state.
} 
because distribution networks are poorly organized and the ability of the poor to pay for diverse water uses is limited. The struggle between community and formal rules of water allocation are often accommodated, but not solved, within a pluralistic setting (MeinzenDick and Pradhan 2002; Neef et al. 2006). It is also important to study the non-decisions, the submerged politics and hidden contests that result in decisions regarding who gets what and how much (Lebel et al. 2007; Molle et al. 2009). Many allocation mechanisms are of this sort-illegal pumping, non-payment of use fees, politically connected benefits from infrastructure, and so on-and their underlying narratives and discourses deserve study.

Discourses and rules at the national level are often influenced by practices at the international level, through development cooperation (Matz 2008; Sacher and Windfur 2008), development banks (Hartje 2008) and international social movements (e.g. against large dams). These aspects of globalization often attempt at creating homogenous rules that then faces resistance (Nakashima and Chiba 2006).

Sharing the risks associated with water use and management is also complicated. For example, the river Kosi breached its embankments in 2008 displacing 45,000 people in Nepal and 3.5 million in one of the poorest states in India-Bihar. Allocating responsibilities for such breaches is very complex within and between poorer governance entities (Dixit 2009; Mishra 2008); not least because Bihar probably receives less attention within India; and because of the institutional complexities (Shrestha et al. 2010).

Responsibility for harm caused is also contested. McCaffrey (2001) argues that although the no-harm principle exists, it is not absolute; the harm caused must be significant, there must be a failure of due care and diligence, and the complaint of the complaining state should be seen as reasonable. Within states, the responsibility for causing harm has developed differently in different parts of the world (Dellapenna and Gupta 2009).

There is no coordinated global scientific effort on water; and scientific work on water access and allocation has been promoted by concerns regarding potential water conflict. However, more scientific work has been undertaken on issues such as integrated water resource management where access and allocation issues are only one of several (Conca 2006; Hooper 2005) and often trade-offs are made. The 'virtual water' discourse may change the nature of the discussions (Neubert 2008). Social movements on water are dispersed but have a long pedigree. Access to judicial systems of other countries on water related issues exist in parts of Europe and the Southern African Development Community countries and this increases the legal remedies available for those whose rights have been violated; access in national contexts varies from place to place.

Although there is enough fresh water globally, regional variations in water combined with institutionalized rules regarding water access through diverging historical processes, imply that access and allocation issues continue to remain on the agenda. Even partially ${ }^{5}$ addressing the access issue by implementing the Millennium Development Goals may not imply that the problem is addressed in the post-2015 period since climate change may further exacerbate regional differences. Access and allocation in water is seen as cause of both conflict and peace, and the resource itself is seen as highly valuable-'blue gold' (Barlow and Clarke 2002) —and this will justify the political struggle to control it. However, access and allocation issues may not always nicely fit into the integrated water resource/river basin management paradigms (Hooper 2005) and optimal management solutions may or may not lead to further inequities (Molle 2008).

\footnotetext{
5 The Millennium Development Goals only aim to halve the number of people without access; and not to address the problem of people without access.
} 


\section{Climate change governance}

Unlike water, climate change governance is relatively young, going back only two decades. While there have been attempts to frame the climate change issue as essentially an environmental, technological and economic issue, the heart of the problem are the complex distributional issues (Banuri et al. 1996; Gupta 1997). The 2009 Copenhagen conference of the parties to the Climate Convention failed to adopt a legally binding agreement but finally succeeded in bringing the issue to the top of the political agenda as some 120 heads of state and government attended this meeting. This section discusses some general paradigmatic challenges, and then elaborates on the access and allocation dimensions before briefly touching on the role of science.

The issue of climate change brings a number of struggles to the fore. The key conflicts are: the struggle between current modes of development and what their environmental impacts imply for development paradigms and production and consumption patterns in general; and the struggle for control over the limited ecospace-the limited amount of permissible greenhouse gas emissions which decreases every year and is possibly exhausted by 2036 if the global community wishes to keep the climate change problem within 'safe' limits (UNDP 2007). This struggle is not only witnessed at North-South level but also within regions and countries. Both these call for multi-disciplinary research. The third element of this power struggle is the element of denial-denying that impacts are caused by actions elsewhere either through scientific sophistry (how does one differentiate between climate variability and climate change; how can one attribute one impact to one emitter and so on) or legal argumentation (how much harm is needed for the no-harm principle; can the polluter pays principle be applied internationally). This is critical for those causing harm to avoid potential lawsuits that can run into the billions of Euros.

Applying our framework to climate change, access can be defined in terms of access to minimum resources and ecospace (the per capita minimum right to emit greenhouse gases) and access to security (that is, that basic human rights are not jeopardized by the impacts of climate change).

Climate change is caused by the emissions of greenhouse gases. In terms of mitigation efforts, a debate has evolved around whether one should consider gross or per capita emissions. In terms of gross emissions, China and India are among the top polluting countries in the world. However, in terms of per capita emissions their emissions are much lower. A gross emission approach would deny that each individual has a right to survive and thus cause emissions. From an access perspective, a key question is what is the absolute minimum level of emissions compatible with basic survival? The literature argues that none of the Millennium Development Goals can be achieved without providing the poorest access to a minimum level of energy and in that sense an implicit discussion on survival emission rights is emerging.

In terms of adaptation, the access to security implies not having basic rights violated. This is perhaps less contested, but the discussion is also much newer. This is the emerging right that no violation of human rights should occur because of global environmental problems. For example, children, symbolic of the future generation, are likely to have their basic rights affected by climate change (Arts 2009). But as even present generations are likely to be affected, climate change could imply a violation of the human rights of some people by affecting their access to food and water and by influencing their livelihoods and homes (UNDP 2007: 60).

As highlighted before, allocation has three dimensions: allocation of resources; allocation of burdens and risks; and allocation of responsibilities for causing problems. 
With respect to climate change, the allocation of resources is about how the ecospace is shared between countries. Because the ecospace is very limited (especially if global emissions are to peak in 2015), the allocation discussion becomes very similar to the access discussion. The per capita argument mentioned above is significant because it is based on the idea that greenhouse gas emissions are closely linked to the development levels of countries and peoples and that reducing emissions for the poorer countries would impact on their ability to develop. This right to emit runs parallel to the demand of the developing countries of the right to develop which was finally adopted in the 1986 Declaration on the Right to Development. This right is an "inalienable human right by virtue of which every human person and all peoples are entitled to participate in, contribute to, and enjoy economic, social, cultural and political development" and "the exercise of their inalienable right to full sovereignty over all their natural wealth and resources" (UN Declaration on the Right to Development 1986). This idea is referred to in the Climate Convention (UNFCCC 1992: Preambular paras. 3 and 23, and Art. 4(5)) and the literature (Baer et al. 2008; Meyer 2000; Phylipsen et al. 1998) but is contested because such a right is not seen as comparable to the right to education (e.g. UNDP 2007, 50), or because it is incompatible with addressing the problem (e.g. Weisslitz 2005), or because the right to development is for individuals and not states and hence states cannot claim this right (Piron 2002), or because this right can be translated into a "right to everything" (Kirchmeier 2006). The allocation of rights to emit is likely to become a serious domestic issue as and when countries have to determine who should have access and who not. A second related argument is that one cannot compare survival emissions with luxury emissions (Agarwal and Narain 1991), since there are few alternatives for those who are marginalized in comparison to the rich.

In the early 1990s, there were negotiations on the relevant criteria for sharing permissible global emissions, as this was pertinent to emissions trading; however, the complexity of the negotiations led these issues to be discarded from the agenda. By 1996 this was again an issue. Emission allocations based on a per capita right provides the 150 developing countries the bulk of the emission rights. Emission allocations based more or less on grandfathering ${ }^{6}$ principles provides the 40 developed countries the bulk of the emission rights. The compromise in the Kyoto Protocol of 1997 is that the developed countries received emission rights more or less equal to their grandfathered rights; while developing countries have no limits. While this may sound like a fair solution, this has set the precedent of grandfathering.

The allocation of environmental responsibilities from the perspective of 'who is responsible' could be undertaken in terms of the polluter pays principle, the no-harm principle, the liability, and compensation principles (Gupta 1997; Kanie et al. 2010). Although pre-1990 political declarations indicate that funding would be needed to compensate developing countries (Gupta 1998) and that such resources should be new and additional to official development assistance, the need to avoid liability led to these principles morphing into the euphemistic "special responsibility" idea (ECE Declaration 1990) and into the common but differentiated responsibility approach that is based more on capabilities than liability (Sands 1995: 650). Finally, the euphemistic 'leadership' principle was adopted in terms of the principle of common but differentiated responsibilities and

\footnotetext{
${ }^{6}$ Grandfathering implies allocating emissions in accordance with current emission levels. The current emission levels of the developed countries is very closely linked to their current emissions levels and they have only to reduce their joint emissions by $5.2 \%$ in the Kyoto Protocol period of 2008-2012.
} 
respective capabilities (UNFCCC 1992, Art. 3). ${ }^{7}$ Moreover, this was only half-heartedly implemented. Recent proposals for allocating responsibilities range from critiquing the foundations of the common but differentiated responsibility and respective capability principle (Weisslitz 2005; Adams 2003, shades of the life-boat theory-Hardin 1974) to arguing that it is necessary (Rajamani 2000; Anand 2004; Batruch 1999) and translating it into proposals (e.g. Baer et al. 2008; Meyer 2000; Phylipsen et al. 1998; Gupta 2008; Agarwal 2000; Kanie et al. 2010). Clearly this is not only an argument that plays out at international level, but will increasingly become important domestically especially in countries with large disparities in wealth.

The allocation of burdens and risks from the perspective of the affected has not been the subject of much discussion in the negotiations. The bulk of the serious impacts will further marginalize the developing countries and poor communities living in marginal areas of the earth. Changing rainfall patterns and rising sea levels will affect their livelihoods and lives (IPCC-2 2007). The Convention adopted the notion of paying for full incremental costs (Arts. 4.3 e; Art 4.4 and 4.8), which only implies paying for global benefits not local benefits. Since adaptation was seen as generating only local benefits, there was no incentive for the developed countries to pay for these (Bodansky 1993, 528). The need for 'new and additional' resources discussion has also evaporated in the current discourse on "mainstreaming climate change into development cooperation" (Gupta and van der Grijp 2010). However, at Copenhagen in 2009, the developed countries said that they would raise 30-120 billion USD in the period up to 2020 to finance mitigation and adaptation costs and this raises issues-about how these funds will both be raised and spent.

The equity discussion in the climate treaty serves as a fig leaf to hide the fact that those responsible for causing the problem are not held accountable; and that the debate is marred in power politics at the global level. Worse, with the adoption of the emissions trading concept in the Kyoto Protocol of 1997, the polluter was paid. This was because instead of the largest polluters being held accountable for their pollution, they were allowed to trade; and those with the greatest systemic inefficiencies can gain the most in such a system. The grandfathering principle is rooted in the prior appropriation system, which allows those who appropriate a large proportion of the earth's environmental space to get access to larger allowances that they can subsequently convert into monetary gain through trade.

A challenge in the adaptation and mitigation discussion is that the more one mitigates the less there is need to adapt, but also mitigation becomes less urgent since one needs to adapt. Furthermore, if allowances are shared equitably, this will have impacts on both mitigation and adaptation responsibilities. The tradeoffs between these approaches need further research. These discourses are used in multiple manners in the climate negotiations. Allocation challenges domestically have yet to start, but this debate will focus on who gets what level of protection from the impacts of climate change and who will pay for this protection.

In relation to access to processes, social movements on climate change are increasingly gathering momentum. Cities and local governments have long cooperated under

\footnotetext{
7 The parties should protect the climate system for the benefit of present and future generations of humankind, on the basis of equity and in accordance with their common but differentiated responsibilities and respective capabilities. Accordingly, the developed country parties should take the lead in combating climate change and the adverse effects thereof. [emphasis mine]. The leadership dimension in the treaty is also spread throughout the text calling for the developed countries to take action first (Preamble, Art. 3.1, 4), to assist developing countries (Arts. 3.2, 4.3, 4.4, 4.5. 4.8, 11, 21), to recognize the growth needs of developing countries (Preamble and Art. 3.4) and that the obligation of developing countries is conditional on assistance (Art. 4.7).
} 
movements pushed by the International Coalition of Local Environmental Initiatives (Burkeley and Betsill 2003). While the environmental movement cooperates and coordinates under the banner of the Climate Action Network (Dombrowski 2010), increasingly other groups are organizing themselves—such as Women for Climate Justice. A climate justice movement is gathering momentum using both lobbying efforts and litigation to push the climate change issue further. Access and allocation issues can to some extent be addressed by technological solutions on the mitigation side (e.g. the electric car; second and third generation biofuels) and on the adaptation side (e.g. geo engineering solutions).

\section{Comparative analysis}

Access and allocation issues in the water and climate change domains differ in several ways (Table 2).

First, rules on water access and allocation have a longer history of institutionalization from local through to international level—with at least 3,600 water agreements and 400 since 1820 (Oregon State University 2002) — although at global level, this is not the case. Rules on climate change access and allocation have a very short history of institutionalization and are more developed at the international level than the national level. Global water governance is a network of governance efforts (Pahl-Wostl et al. 2008; Conca 2006), while climate change governance is one of the most centralized systems of governance.

Second, in terms of problem definition, access and allocation issues evoke different challenges in the different fields. Access to water is primarily about access to basic drinking water and sanitation services. Access in climate change is about access to emission allowances for the poorest (survival emissions; right to develop), and access to security to ensure that basic survival is not threatened by the impacts of climate change. Access issues in the climate governance arena have higher political stakes. If the global community were to allocate every human being a per capita right to emit greenhouse gases, there would probably be no excess amounts over to debate the allocation issue. Besides, such a process would call for large transfers of resources from North to South and is very

Table 2 Differences in problem definition of access and allocation between water and climate change

\begin{tabular}{|c|c|c|}
\hline & Water & Climate Change \\
\hline Access & $\begin{array}{l}\text { Right to drinking water and to sanitation } \\
\text { infrastructure/services }\end{array}$ & $\begin{array}{l}\text { Right to develop for individuals: Access to } \\
\text { minimum emission rights for humans; } \\
\text { Access to security: basic survival should not } \\
\text { be impacted by climate change }\end{array}$ \\
\hline Allocation & $\begin{array}{l}\text { Division of water resources between and } \\
\text { among peoples and among different uses; } \\
\text { Division of risks (e.g. floods); Responsibility } \\
\text { for harm (e.g. the no-harm principle) }\end{array}$ & $\begin{array}{l}\text { Right to develop for nations: Need for 'room to } \\
\text { grow'; survival versus luxury emissions; } \\
\text { Division of emission allocations between and } \\
\text { within countries; Division of responsibility } \\
\text { for causing harm; Division of responsibility } \\
\text { for impacts between and within countries }\end{array}$ \\
\hline $\begin{array}{l}\text { Science } \\
\text { and } \\
\text { Action }\end{array}$ & $\begin{array}{l}\text { Science: strong epistemic community on } \\
\text { Integrated Water Resources Management, } \\
\text { but not necessarily on access and allocation; } \\
\text { Social movements: locally organized; Access } \\
\text { to courts: differential in different parts of the } \\
\text { world }\end{array}$ & $\begin{array}{l}\text { Science: Strong epistemic community in } \\
\text { IPCC, but access and allocation issues are } \\
\text { given less attention; Social movements: from } \\
\text { local through national to global scale; Access } \\
\text { to courts: limited scope }\end{array}$ \\
\hline
\end{tabular}


unlikely. While access to water is essentially a local issue although it can be internationalized; access in climate change is essentially a global issue.

Allocation in water is about how water is shared between its different uses for users nationally and internationally, how risks are distributed and how the no harm principle is interpreted. Allocation in climate change is about how emission allowances are shared between and among countries over and above the basic rights, and how responsibilities for, and the costs of coping with, the impacts are distributed between and among countries.

Third, access and allocation issues in water began with struggles at local through to national level and have become a global multi-level issue over the centuries. In climate change, the access and allocation issues are presently being contested at the global level and the European Union level, but will soon become major sites of conflict at national and local level.

Fourth, in terms of norms and discourses, the access to water issue is dominated by the debate between privatization, property rights, historical rights and the human rights discourses. The access to climate change discussion has been dominated by the debate between survival and luxury emissions, the per capita and the grandfathering discourses and more recently between discussions on the human right to climate change and the right to development.

The international allocation of water resources is dominated by three sets of discourses: (a) the sovereignty, no harm, and equity discourses (pushed by the legal community), (b) the integrated river basin management paradigm (pushed by the water science community), and (c) the virtual water trade discussions. The allocation debate in climate change has been raging since the 1990s and the discourse that has won thus far is the 'grandfathering' discourse over the equity discourse on sharing emission allowances between countries. Furthermore, in raising resources for adaptation (prevention, post-impact assistance, and residual impacts) a number of equity discourses are being debated ranging from voluntary contributions out of good will, through responsibility and solidarity principles. The allocation discourses receive greater attention in both cases than the access discourses.

Fifth, in terms of power struggles, the two issues are very different. Power struggles on water are essentially local and regional in nature, although patterns of power struggles may repeat themselves from place to place. Climate change power struggles are global in nature; and there are higher political stakes involved. These struggles will repeat themselves from global through to local level, as discussions about who has the right to emit and how responsibilities for adaptation are to be distributed will play out at the different levels of governance.

Finally, in terms of scale, patterns of problem solving in both water and climate change reveal that while some ideologies transcend the level of governance (e.g. the privatization discourse), others reveal that solutions are often limited to particular levels of governance (e.g. countries may be more willing to discuss solidarity internally than globally).

\section{Conclusion}

This article set out to explore the concepts of access and allocation in theory and practice. Based on this article, we argue that in the area of environmental governance, where resources and ecospace are scarce especially in the context of rising populations and consumption patterns, and the increasing recognition of the importance of maintaining ecosystem services, the issues of access and allocation will become a significant element of global to local politics. While the specific governance challenges vary by issue domain, for 
example because some have had a longer period of institutionalization and path dependency than others or the combination of actors and knowledge available are different (Lebel et al. 2010), and although this article focused on access and allocation in climate change and water, it is clear that these are also highly contentious issues in other areas. For instance, in biodiversity the debate is on access and benefit sharing; in the area of fishing the problem is the multiple competing systems of governance (Burght 2010); in the area of investment the debate is currently on whether rules tend to empower the investor at the cost of others; in the area of trade battles are being, inter alia, fought about the role of intellectual property rights in reducing access and compromising allocation issues.

Scarcity and the power struggles to control resources and ecospace, however, can be dealt with in a number of different ways and different disciplines help provide guidance about how to frame research questions and identify answers. There is a risk however in mono-disciplinary approaches; multi-disciplinary approaches provide more room to identify new and novel solutions to potential conflict situations. Evidence for this can be found in integrative bargaining theory approaches. Hence, we propose a multi-disciplinary framework with initial research questions to guide the study of access and allocation (see Table 1 and Fig. 1). We believe that systematic application of such a framework to the collection of data will facilitate analysis of how such scarce resources can be governed more effectively.

Finally, a comparative study of how access and allocation are dealt with in different fields of governance and in different levels and nodes of governance may reveal consistencies, contradictions, and most importantly lessons that can be applied for sustainable governance.

Access and allocation are contentious political issues in earth system governance because they challenge existing property rights and claims. These topics are therefore a rich area for further research and engagement.

Acknowledgment Louis Lebel's work was funded in part by Echel Eau and the International Fund for Agricultural Development through a grant under the Challenge Programme on Water and Food for project PN50.

Open Access This article is distributed under the terms of the Creative Commons Attribution Noncommercial License which permits any noncommercial use, distribution, and reproduction in any medium, provided the original author(s) and source are credited.

\section{References}

Adams, T. B. (2003). Is there a legal future for sustainable development in global warming? Justice, economics and protecting the environment. Georgetown International Environmental Law Review, 16, 77-126.

Agarwal, A. (2000). Making the Kyoto Protocol work: Ecological and economic effectiveness and equity in the climate regime. New Delhi: CSE statement.

Agarwal, A., \& Narain, S. (1991). Global warming in an unequal world: A case of environmental colonialism. New Delhi: Centre for Science and Environment.

Agnew, J. (2005). Sovereignty regimes: Territoriality and state authority in contemporary world politics. Annals of the Association of American Geographers, 95, 437-461.

Anand, R. (2004). International environmental justice: A North-South dimension. Aldershot: Ashgate Publishing.

Arts, K. (2009). A child rights perspective on climate change. In M. A. Salih (Ed.), Climate change and sustainable development: New challenges for poverty reduction (pp. 79-93). Cheltenham: Edward Elgar. 
Baer, P., Athanasiou, T., Kartha, S., \& Kemp-Benedict, E. (2008). The greenhouse development rights framework: The right to development in a climate constrained world. Berlin: Heinrich Boll Foundation.

Banuri, T., Goran-Maler, K., Grubb, M., Jacobson, H. K., \& Yamin, F. (1996). Equity and social considerations. In J. Bruce, H. Lee, \& E. Haites (Eds.), Climate change 1995: Economic and social dimensions of climate change. contribution of working group III to the second assessment report of the intergovernmental panel on climate change (pp. 79-124). Cambridge, UK: Cambridge University Press.

Barlow, M., \& Clarke, T. (2002). Blue gold: The battle against corporate theft of the world's water. London: Earthscan.

Batruch, C. (1999). Hot air as precedent for developing countries? Equity considerations. UCLA Journal of Environmental Law and Policy, 17, 45.

Benvenisti, E. (2003). Sharing transboundary resources: International law and optimal resource uses. Cambridge, UK: Cambridge University Press.

Biermann, F. (2007). 'Earth system governance' as a crosscutting theme of global change research. Global Environmental Change, 17, 326-337.

Biermann, F., Betsill, M. M., Gupta, J., Kanie, N., Lebel, L., Liverman, D., Schroeder, H., Siebenhüner, B., \& Zondervan, R. (2010). Earth system governance: A research framework. International Environmental Agreements: Politics, Law and Economics, 10(4).

Biermann, F., Betsill, M.M., Gupta, J., Kanie, N., Lebel, L., Liverman, D., Schroeder, H. \& Siebenhüner, B. with contributions from K. Conca, L. da Costa Ferreira, B. Desai, S. Tay, \& R. Zondervan. (2009). Earth system governance: People, places and the planet. Science and implementation plan of the Earth System Governance Project. Earth System Governance Report 1, IHDP Report 20. Bonn, IHDP: The Earth System Governance Project.

Bodansky, D. (1993). The United Nations framework convention on climate change: A commentary. Yale Journal of International Law, 18, 451-588.

Bourquain, K. (2008). Freshwater access from a human rights perspective: A challenge to international water and human rights law. Leiden: Martinus Nijhoff Publishers.

Burght, N. M. J. (2010). The contribution of international fisheries law to human development. Dissertation, VU University, Amsterdam.

Burkeley, H., \& Betsill, M. M. (2003). Cities and climate change: Urban sustainability and global environmental governance. London and New York: Routledge Studies in Physical Geography and the Environment.

Caponera, D. A. (1992). Principles of water law and administration: National and international. Rotterdam: A. A. Balkema Publishers.

Conca, K. (2006). Governing water: Contentious transnational politics and global institution building. Cambridge, MA: MIT Press.

Dellapenna, J. W. (2009). The market alternative. In J. Dellapenna \& J. Gupta (Eds.), The evolution of the law and politics of water (pp. 373-388). Dordrecht: Springer.

Dellapenna, J., \& Gupta, J. (Eds.). (2009). The evolution of the law and politics of water. Dordrecht: Springer.

Dingwerth, K. (2004). The democratic legitimacy of public private rule making: What can we learn from the World Commission on Dams. Global Governance, 11(1), 65-83.

Dixit, A. (2009). Kosi embankment breach in Nepal: Need for a paradigm shift in responding to floods. Economic and Political Weekly, 7 February.

Dombrowski, K. (2010) Filling the gap? An analysis of NGO responses to participation and representation deficits in global climate governance. International Environmental Agreements: Politics, Law and Economics, 10(4).

Donger, W., \& Smith, K. (1991). The laws of Manu. New Delhi: Penguin Classics.

Dore, J., \& Lebel, L. (2010a). Deliberation, scale and the governance of water resources in the Mekong region. Environmental Management, 46, 60-80.

Dore, J., \& Lebel, L. (2010b). Gaining public acceptance: A critical strategic priority of the World Commission on dams. Water Alternatives, 3, 154-171.

Dryzek, J. S. (2000). Deliberative democracy and beyond: Liberals, critics, contestations. Oxford: Oxford University Press.

ECE Declaration (1990). UN/ECE Bergen Ministerial Declaration on Sustainable Development in the ECE Region, Bergen. UN Doc. A/CONF.151/PC/10, Annex I.

Elster, J. (1992). Local justice: how institutions allocate scarce goods and necessary burdens. New York: Russell Sage Foundation.

Elster, J. (2006). Fairness and norms. Social Research, 73, 365-376. 
FCCC. (1992). United Nations Framework Convention on Climate Change, (New York) 9 May 1992, in force 24 March 1994; 31 I.L.M. 1992, p. 822.

Ferguson, J., \& Gupta, A. (2002). Spatializing states: Towards an ethnography of neoliberal governmentality. American Ethnologist, 29, 981-1002.

Fink, M., \& Cramer, A. (2008). Towards implementation of the World Commission on Dams recommendations. In W. Scheumann, S. Neubert, \& M. Kipping (Eds.), Water politics and development cooperation: Local power plays and global governance (pp. 33-54). Dordrecht: Springer.

Fuentes, X. (1999). Sustainable development and the equitable utilization of international watercourses. The British Yearbook of International Law, 1998(1999), 119-200.

General comment No 15. (2002). The right to water, substantive issues arising in the implementation of the International Covenant on Economic, Social and Cultural Rights, UN Economic and Social Council, UN Doc. E/C.12/2000/11 (26 November 2002).

Gupta, J. (1997). The climate change convention and developing countries: From conflict to consensus. Dordrecht: Kluwer Academic Publishers.

Gupta, J. (1998). Leadership in the climate regime: Inspiring the commitment of developing countries in the post-Kyoto phase. Review of European Community and International Environmental Law, 7(2), 178-188.

Gupta, J. (2008). Engaging developing countries in climate change negotiations. Study for the European Parliament's Temporary Committee on Climate Change (CLIM) IP/A/CLIM/IC/2007-111, Institute for European Environmental Policy (IEEP) and Ecologic, Briefing number, pp. 631-715.

Gupta, J., \& van der Grijp, N. (Eds.). (2010). Mainstreaming climate change in development cooperation: Theory, practice and implications for the European Union. Cambridge, UK: Cambridge University Press.

Gupta, J., \& van der Zaag, P. (2008). Interbasin water transfers and integrated water resources management: Where engineering, science and politics interlock. Physics and Chemistry of the Earth, 33, 28-40.

Hardin, G. (1974). Life-Boat ethics: The case against helping the poor. Psychology Today, 8, 38-42.

Hartje, V. (2008). The World Bank's water sector policy reforms. In W. Scheumann, S. Neubert, \& M. Kipping (Eds.), Water politics and development cooperation: Local power plays and global governance (pp. 301-332). Dordrecht: Springer.

Hildering, A. (2005). International law, sustainable development and water management. Delft: Eburon Publishers.

Hooper, B. (2005). Integrated river basin governance: Learning from international experience. London: International Water Association Publishing.

ILA. (1966). The Helsinki Rules on the uses of the waters of international rivers. Report of the Fifty-Second Conference (Helsinki), International Law Association, London.

ILA. (2004). The Berlin Rules on water resources. Report of the seventy-first conference (Berlin), International Law Association, London.

IPCC-2. (2007). Climate Change 2007: Impacts, adaptation and vulnerability. Contribution of Working Group II to the Fourth Assessment Report of the Intergovernmental Panel on Climate Change. Cambridge, UK: Cambridge University Press.

Kanie, N., Hiromi, N., Yasuaki, H., \& Yasuko, K. (2010) Allocation and architecture in climate governance beyond Kyoto: Lessons from interdisciplinary research on target setting. International Environmental Agreements: Politics, Law and Economics, 10(4). doi:10.1007/s10784-010-9143-5.

Kirchmeier, F. (2006). The right to development: Where do we stand? Dialogue on globalization. Occassional Papers, No. 23. Geneva: Friedrich-Ebert-Stiftung.

Lebel, L., Dore, J., Daniel, R., \& Koma, Y. S. (Eds.). (2007). Democratizing water governance in the Mekong region. Chiang Mai: Mekong Press.

Lebel, L., Garden, P., \& Imamura, M. (2005). Politics of scale, position and place in the governance of water resources in the Mekong region. Ecology and Society, 10, 18. URL: http://www.ecologyandsociety. org/vol10/iss12/art18/.

Lebel, L., Grothmann, T., \& Siebenhüner, B. (2010). The role of social learning in adaptiveness: insights from water management. International Environmental Agreements: Politics, Law and Economics, 10(4). doi:10.1007/s10784-010-9142-6.

Luterbacher, U., \& Wiegandt, E. (2005). Cooperation or confrontation: Sustainable water use in an international context. In E. B. Weiss, L. B. de Chazournes, \& N. Bernasconi-Osterwalder (Eds.), Fresh water and international economic law (pp. 11-34). Oxford: Oxford University Press.

Matz, M. (2008). Rethinking IWRM under cultural considerations. In W. Scheumann, S. Neubert, \& M. Kipping (Eds.), Water politics and development cooperation: Local power plays and global governance (pp. 177-201). Dordrecht: Springer. 
McCaffrey, S. C. (1992). A human right to water: Domestic and international implications. Georgetown International Environmental Law Review, 5, 1-23.

McCaffrey, S. C. (2001). The law of international watercourses, non-navigational uses. Oxford: Oxford University Press.

Meinzen-Dick, R. S., \& Pradhan, R. (2002). Legal pluralism and dynamic property rights. CAPRi Working Paper No. 22

Meyer, A. (2000). Contraction and convergence: The global solution to climate change. Schumacher Briefings, No. 5, Green Books for the Schumacher Society. Dartington, Totnes, Devon: Foxhole.

Mishra, D. K. (2008). The Kosi and embankment story. Economic and Political Weekly, India, 15 September.

Modi, V., McDade, S., Lallement, D., \& Saghir, J. (2005). Energy services for the millennium development goals. New York: Energy Sector Management Assistance Programme, United Nations Development Programme, UN Millennium Project, and World Bank.

Molle, F. (2008). Nirvana concepts, narratives and policy models: Insights from the water sector. Water Alternatives, 1(1), 23-40.

Molle, F., Foran, T., \& Kakonen, M. (Eds.). (2009). Contested waterscapes in the Mekong Region: Hydropower, livelihoods and governance. London: Earthscan.

Naff, T. (2008). Islamic law and the politics of water. In J. Dellapenna \& J. Gupta (Eds.), The evolution of the law and politics of water (pp. 37-52). Dordrecht: Springer.

Nakashima, D., \& Chiba, M. (2006). Introduction, water and indigenous peoples. Paris: UNESCO.

Neef, A., Chamsai, L., \& Sangkapitux, C. (2006). Water tenure in highland watersheds of Northern Thailand: Managing legal pluralism and stakeholder complexity. In L. Lebel, X. Jianchu, \& A. Contreras (Eds.), Institutional dynamics and stasis: How crises alter the way common pool resources are perceived, used and governed (pp. 64-88). Regional Centre for Social Science and Sustainable Development (RCSD) Monograph Series, Chiang Mai: Chiang Mai University).

Neubert, S. (2008). Strategic virtual water trade: A critical analysis of the debate. In W. Scheumann, S. Neubert, \& M. Kipping (Eds.), Water politics and development cooperation: Local power plays and global governance (pp. 123-146). Dordrecht: Springer.

Oregon State University. (2002). Atlas of international freshwater agreements. Nairobi: UNEP.

Pahl-Wostl, C., Gupta, J., \& Petry, D. (2008). Governance and the global water system: A theoretical exploration. Global Governance, 14(4), 419-436.

Petrella, R. (2001). The Water Manifesto: Arguments for a world water contract. London: Zed Books.

Phylipsen, G. J. M., Bode, J. W., Blok, K., Merkus, H., \& Metz, B. (1998). A triptych sectoral approach to burden differentiation; GHG emissions in the European bubble. Energy Policy, 26(12), 929-943.

Piron, L.-H. (2002). The right to development: A review of the current state of the debate. London: Department of International Development.

Rajamani, L. (2000). The principle of common but differentiated responsibility and the balance of commitments under the climate regime. Review of European Community and International Environmental Law, 9, 120.

Rangarajan, L. N. (1987). Kautilya's arthashastra. New Delhi: Penguin Classics.

Ribot, J., \& Peluso, N. L. (2003). A theory of access. Rural Sociology, 68, 153-181.

Rorty, R. (1992). A pragmatic view of rationality and cultural difference. Philosophy of East and West, 42, 581-596.

Sacher, D., \& Windfur, M. (2008). The debate on "Water as a Human Right" and its implications for development assistance. In W. Scheumann, S. Neubert, \& M. Kipping (Eds.), Water politics and development cooperation: Local power plays and global governance (pp. 147-176). Dordrecht: Springer.

Salman, S. M. A., \& Uprety, K. (2002). Conflict and cooperation on South Asia's international rivers: A legal perspective. The Hague: Kluwer International Law.

Sands, P. (1995). Principles of international environmental Law, Vol. I, Frameworks, standards and implementation. Manchester: Manchester University Press.

Scheumann, W. (2008). How global norms for dams reach decision-makers. In W. Scheumann, S. Neubert, \& M. Kipping (Eds.), Water politics and development cooperation: Local power plays and global governance (pp. 55-80). Dordrecht: Springer.

Schouten, M., \& Schwartz, K. (2006). Water as a political good: Implications for investments. International Environmental Agreements: Politics. Law and Economics, 6(4), 407-421.

Schrijver, N. (1995). Sovereignty over natural resources: Balancing rights and duties in an interdependent world. Dissertation, University of Groningen. 
Shrestha, R. K., Ahlers, R., Bakker, M., \& Gupta, J. (2010). Institutional Dysfunction and challenges in flood control: A case study of the Kosi Flood 2008. Economic and Political Weekly, 45(2), 45-53 Available at http://epw.in/epw/uploads/articles/14331.pdf.

Smets, H. (2000). The right to water as a human right. Environmental Policy and Law, 30(5), 248-250.

Tarlock, D. (2005). Water transfers: A means to achieve sustainable water use. In E. B. Weiss, L. de Boisson Chazournes, \& N. Bernasconi-Osterwalder (Eds.), Fresh water and international economic law (pp. 35-60). Oxford: Oxford University Press.

Tecco, N. (2008). Financially sustainable investments in developing countries water sectors: what conditions could promote private sector involvement? International Environmental Agreements: Politics, Law and Economics, 8(2), 129-142.

Teclaff, L. A. (1985). Water law in historical perspective. Buffalo \& New York: W.S. Hein.

Tienhaara, K. (2009). The expropriation of environmental governance: Protecting foreign investors at the expense of public policy. Cambridge, UK: Cambridge University Press.

UNCED. (1992). United Nations Conference on Environment and Development; Rio Declaration and Agenda 21. Report on the UN Conference on Environment and Development, Rio de Janeiro, 3-14 June 1992, UN Doc. A/CONF.151/26/Rev.1 (Vols. 1-III).

UNDP. (2007). Human Development Report 2007/2008: Fighting climate change-Human solidarity in a divided world. New York: United Nations Development Programme.

UN Declaration on the Right to Development. (1986). UN High Commission on Human Rights, Declaration on the right to development, United Nations General Assembly Resolution 41/128 of 4 December 1986. Online: http://www.un.org/en/documents.

UN Energy. (2005). The energy challenge for achieving the millennium development goals, UN Energy. [online: http://esa.un.org/un-energy]UNFCCC 1992. United Nations Framework Convention on Climate Change, 31 I.L.M. 1992, 822.

UN Watercourses Convention (1997). UN Convention on the Law of the Non-Navigational Uses of International Watercourses, (IWC) (1997), UN Doc. A/51/869; 37 ILM 719.

WECF. (2008). Europe's sanitation problem: 20 million Europeans need access to safe and affordable sanitation. Utrecht: Women in Europe for a Common Future.

Weisslitz, M. (2005). Rethinking the equitable principle of common but differentiates responsibility: differential versus absolute norms of compliance and contribution in the global climate change context. Colorado Journal of International Environmental Law and Policy, 13, 473.

Young, I. M. (2001). Activist challenges to deliberative democracy. Political Theory, 29(5), 670-690. 